\title{
HUBUNGAN KEBIASAAN MEROKOK DENGAN STATUS GINGIVA PADA REMAJA USIA 15-19 TAHUN
}

\author{
${ }^{1}$ Katarina D. Manibuy \\ ${ }^{2}$ Damajanty H. C. Pangemanan \\ ${ }^{3}$ Krista V. Siagian
}

\author{
${ }^{1}$ Kandidat Skripsi Program Studi Pendidikan Dokter Gigi Fakultas Kedokteran \\ ${ }^{2}$ Bagian Fisiologi Fakultas Kedokteran \\ ${ }^{3}$ Program Studi Pendidikan Dokter Gigi Fakultas Kedokteran \\ Universitas Sam Ratulangi Manado \\ E-mail:katarinadesymanibuy@ymail.com
}

\begin{abstract}
Currently, smokers in Indonesia have already included teenagers. Adolescent phase is particularly vulnerable to try new things with the purpose of identity searching, one of which is through smoking. Smoking does not only cause a systemic effect on the body, but can also cause pathologic conditions in the oral cavity such as gingivitis. Accumulation of heat and combustion products of cigarettes can affect the response of gingival inflammation. The objective of this study was to determine the relation between smoking habits based on the amount and duration of smoking cigarettes with gingival status in adolescents aged 15-19 years in Tuminting district.This research was descriptive analytic with cross sectional approach. The population was all adolescents aged 15-19 years in Tuminting district. A sample of 99 adolescents was taken using proportional random sampling. The data were collected using questionnaires and checks on gingival status by gingival index.The research findings show that as many as 49 adolescents (49.5\%) had a mild smoking habit based on the number of cigarettes (1-4 cigarettes/day), 39 adolescents (39.4\%) had a heavy smoking habit by smoking duration (>2 years) and 70 adolescents (70.7\%) had mild gingival status. Chi-square test results show no significant relation between smoking habits based on the amount of cigarettes smoked and gingival status ( $>0.05$ ), but smoking habits based on the duration of smoking relate to gingival status $(\mathrm{p}<0.05)$.
\end{abstract}

Keywords: smoking habit, gingival status, adolescents

\begin{abstract}
Abstrak:Saat ini, perokok di Indonesia sudah mencakup ke kalangan remaja. Fase remaja sangat rentan untuk mencoba hal-hal baru dengan tujuan untuk pencarian jati dirinya, salah satunya yaitu dengan caramerokok. Kebiasaan merokok tidak hanya menimbulkan efek sistemik pada tubuh, tetapi juga dapat menimbulkan kondisi patologis di rongga mulut, salah satunya yaitu gingivitis.Panas dan akumulasi produk hasil pembakaran rokok dapat memengaruhi respon inflamasi gingiva. Tujuan penelitian ini untuk mengetahui hubungan kebiasaan merokok berdasarkan jumlah rokok dan lama merokok dengan status gingiva pada remaja usia 15-19 tahun di kecamatan Tuminting.Penelitian ini merupakan penelitian deskriptif analitik dengan pendekatan cross sectional. Populasi penelitian ialah seluruh remaja usia 15-19 tahun di kecamatan Tuminting. Jumlah sampel 99 orang diambil dengan caraproportional random sampling. Pengumpulan data menggunakan kuesioner dan pemeriksaan status gingiva berdasarkan indeks gingiva.Hasil penelitian ini menunjukkan bahwa sebanyak 49 orang (49,5\%) memiliki kebiasaan merokok ringan berdasarkan jumlah rokok (1-4 batang rokok/hari), 39 orang $(39,4 \%)$ memiliki kebiasaan merokok berat berdasarkan lama merokok (>2 tahun), 70 orang (70,7\%) yang memiliki status gingiva ringan. Hasil uji chi-sqaure menunjukkan bahwa tidak terdapat hubungan antara kebiasaan merokok berdasarkan jumlah rokok dengan status gingiva $(\mathrm{p}>0,05)$ namun kebiasaan merokok berdasarkan lama merokok berhubungan dengan status gingiva $((\mathrm{p}<0,05)$.
\end{abstract}

Kata kunci: kebiasaan merokok, status gingiva, remaja 
Masa remaja atau masa adolescence ialah suatu fase tumbuh kembang yang dinamis dalam kehidupan seorang individu. Fase remaja ini sangat rentan untuk mencoba hal-hal baru dan modern dengan tujuan untuk pencarian jati dirinya, yaitu salah satunya dengan cara merokok. ${ }^{1}$ Sejumlah studi menyebutkan bahwa usia pertama kali merokok pada umumnya dimulai pada usia 11-13 tahun dan 85-90\% mulai merokok sebelum usia 18 tahun. ${ }^{2,3}$

Kebiasaan merokok tidak hanya menimbulkan efek secara sistemik seperti kanker paru, penyakit kardiovaskuler, risiko terjadinya neoplasma larynx, esophagus, tetapi juga dapat menimbulkan kondisi patologis di rongga mulut, salah satunya yaitu penyakit periodontal. Hal ini disebabkan karena rongga mulut merupakan tempat terjadinya penyerapan zat hasil pembakaran rokok, terutama jaringan lunak mulut yang lebih rentan terpapar efek rokok. ${ }^{4}$

Gingiva ialah salah satu bagian jaringan lunak mulut.Gingiva berfungsi sebagai struktur penunjang jaringan keras gigi. Perubahan panas dan akumulasi produk-produk hasil pembakaran rokok dapat memengaruhi respon inflamasi gingiva. ${ }^{5}$ Menurut data RISKESDAS 2013, prevalensi penduduk umur 15-19 tahun yang merokok setiap hari di Sulawesi Utara sebesar 13,2\%. Data ini lebih tinggi dibandingkan prevalensi nasional merokok setiap hari umur 15-19 tahun sebesar 11,2\%. ${ }^{6}$ Prevalensi merokok pada laki-laki umur 15-19 tahun lebih tinggi sebesar $37,3 \%$ dibanding pada perempuan sebesar $3,1 \%{ }^{7}$

Kecamatan Tuminting merupakan kecamatan yang letaknya berada di pinggiran kota Manado. Sosial ekonomi serta latar belakang pendidikan masyarakatnya masih rendah karena kebanyakan berprofesi sebagai nelayan tradisional. ${ }^{8}$ Menurut data RISKESDAS 2013, berdasarkan jenis pekerjaan, petani, nelayan dan buruh ialah perokok aktif setiap hari yang mempunyai proporsi terbesar (44,5\%) dibandingkan kelompok pekerjaan lainnya. ${ }^{6}$ Remaja cenderung mengikuti perilaku orang-orang di sekitarnya seperti mengikuti perilaku orang tuanya, yaitu mengikuti perilaku kebiasaan merokok. ${ }^{9}$ Berdasarkan latar belakang di atas maka peneliti tertarik ingin melihat hubungan kebiasaan merokok dengan status gingiva pada remaja usia 15-19 tahun di kecamatan Tuminting.

\section{BAHAN DAN METODE PENELITIAN}

Penelitian ini merupakan penelitian deskriptif analitik dengan pendekatan cross sectional. Penelitian dilakukan di kecamatan Tuminting pada bulan AgustusSeptember 2015. Populasi penelitian ini ialah seluruh remaja usia 15-19 tahun di kecamatan Tuminting dengan jumlah populasi 5076 orang. Sampel penelitian ini ialah remaja usia 15-19 tahun yang memiliki kebiasaan merokok di kecamatan Tuminting yang memenuhi kriteria inklusi dan ekslusi. Teknik pengambilan sampel dengan proportional random sampling dengan besar sampel yaitu 99 orang.

Pengambilan data diambil dengan mengisi kuesioner dan pemeriksaan status gingiva berdasarkan indeks gingiva pada remaja usia 15-19 tahun yang memiliki kebiasaan merokok di kecamatan Tuminting.

\section{HASIL PENELITIAN}

Tabel 1. Distribusi responden berdasarkan jenis kelamin

\begin{tabular}{ccc}
\hline Jenis kelamin & $\mathrm{n}$ & $\%$ \\
\hline Laki-laki & 80 & 80,8 \\
Perempuan & 19 & 19,2 \\
Total & 99 & 100,0 \\
\hline
\end{tabular}

Tabel 2. Distribusi responden berdasarkan usia

\begin{tabular}{ccc}
\hline Usia & $\mathrm{n}$ & $\%$ \\
\hline 15 & 22 & 22,2 \\
16 & 18 & 18,2 \\
17 & 13 & 13,1 \\
18 & 15 & 15,2 \\
19 & 31 & 31,3 \\
Total & 99 & 100,0 \\
\hline
\end{tabular}


Tabel 3. Distribusi frekuensi kebiasaan merokok berdasarkan jumlah rokok

\begin{tabular}{cccr}
\hline $\begin{array}{c}\text { Kebiasaan } \\
\text { merokok }\end{array}$ & $\begin{array}{c}\text { Jumlah rokok } \\
\text { (batang/hari) }\end{array}$ & $\mathrm{n}$ & $\%$ \\
\hline Ringan & $1-4$ & 49 & 49,5 \\
Sedang & $5-14$ & 22 & 22,2 \\
Berat & $>14$ & 28 & 28,3 \\
Total & & 99 & 100,0 \\
\hline
\end{tabular}

Tabel 4. Distribusi frekuensi kebiasaan merokok berdasarkan lama merokok

\begin{tabular}{cccc}
\hline $\begin{array}{c}\text { Kebiasaan } \\
\text { merokok }\end{array}$ & $\begin{array}{c}\text { Lama } \\
\text { merokok } \\
\text { (tahun) }\end{array}$ & $\mathrm{n}$ & $\%$ \\
\hline Ringan & $<1$ & 37 & 37,4 \\
Sedang & $1-2$ & 23 & 23,2 \\
Berat & $>2$ & 39 & 39,4 \\
Total & & 99 & 100,0 \\
\hline
\end{tabular}

Tabel 5. Distribusi status gingiva berdasarkan indeks gingiva

\begin{tabular}{ccc}
\hline $\begin{array}{c}\text { Status gingiva berdasarkan } \\
\text { indeks gingiva }\end{array}$ & $\mathrm{n}$ & $\%$ \\
\hline Sehat & 3 & 3,0 \\
Ringan & 70 & 70,7 \\
Sedang & 26 & 26,3 \\
Berat & 0 & 0,0 \\
Total & 99 & 100,0 \\
\hline
\end{tabular}

Tabel 6. Hasil tabulasi silang kebiasaan merokok berdasarkan jumlah rokok dengan status gingiva

\begin{tabular}{|c|c|c|c|c|c|c|c|c|c|c|}
\hline \multirow{3}{*}{$\begin{array}{c}\text { Kebiasaan } \\
\text { merokok } \\
\text { berdasarkan } \\
\text { jumlah rokok }\end{array}$} & \multicolumn{8}{|c|}{$\begin{array}{c}3 \\
\text { Status Gingiva } \\
\end{array}$} & \multirow{2}{*}{\multicolumn{2}{|c|}{ Total }} \\
\hline & \multicolumn{2}{|c|}{ Sehat } & \multicolumn{2}{|c|}{ Ringan } & \multicolumn{2}{|c|}{ Sedang } & \multicolumn{2}{|c|}{ Berat } & & \\
\hline & $\mathrm{n}$ & $\%$ & $\mathrm{n}$ & $\%$ & $\mathrm{~N}$ & $\%$ & $\mathrm{n}$ & $\%$ & $\mathrm{n}$ & $\%$ \\
\hline Ringan & 3 & 6,1 & 35 & 71,4 & 11 & 22,5 & 0 & 0,0 & 49 & 100,0 \\
\hline Sedang & 0 & 0,0 & 19 & 86,4 & 3 & 13,6 & 0 & 0,0 & 22 & 100,0 \\
\hline Berat & 0 & 0,0 & 16 & 57,1 & 12 & 42,9 & 0 & 0,0 & 28 & 100,0 \\
\hline
\end{tabular}

Tabel 7. Hasil tabulasi silang kebiasaan merokok berdasarkan jumlah rokok dengan status gingiva

\begin{tabular}{|c|c|c|c|c|c|c|c|c|c|c|}
\hline \multirow{3}{*}{$\begin{array}{c}\text { Kebiasaan } \\
\text { merokok } \\
\text { berdasarkan } \\
\text { lama merokok }\end{array}$} & \multicolumn{8}{|c|}{$\begin{array}{c}3 \\
\text { Status Gingiva } \\
\end{array}$} & \multirow{2}{*}{\multicolumn{2}{|c|}{ Total }} \\
\hline & \multicolumn{2}{|c|}{ Sehat } & \multicolumn{2}{|c|}{ Ringan } & \multicolumn{2}{|c|}{ Sedang } & \multicolumn{2}{|c|}{ Berat } & & \\
\hline & $\mathrm{n}$ & $\%$ & $\mathrm{n}$ & $\%$ & $\mathrm{n}$ & $\%$ & $n$ & $\%$ & $\mathrm{n}$ & $\%$ \\
\hline Ringan & 3 & 8,1 & 27 & 73,0 & 7 & 18,9 & 0 & 0,0 & 37 & 100,0 \\
\hline Sedang & 0 & 0,0 & 20 & 87,0 & 3 & 13,0 & 0 & 0,0 & 23 & 100,0 \\
\hline Berat & 0 & 0,0 & 23 & 59,0 & 16 & 41,0 & 0 & 0,0 & 39 & 100,0 \\
\hline
\end{tabular}

\section{BAHASAN}

Tabel 1 menunjukkan bahwa responden dengan jenis kelamin laki-laki (80,8\%) lebih banyak dari responden berjenis kelamin perempuan (19,2\%).

Distribusi responden berdasarkan usia menunjukkan bahwa usia terbanyak pada
19 tahun (31,3\%), diikuti usia 15 tahun (22,2\%), usia 16 tahun (18,2\%), usia 18 tahun $(15,2 \%)$ dan usia 17 tahun $(13,1 \%)$ (Tabel 2).

Data distribusi kebiasaan merokok berdasarkan jumlah rokok menunjukkan bahwa responden terbanyak yaitu yang 
menghisap 1-4 batang rokok / hari dan termasuk dalam kebiasaan merokok ringan (49,5\%), diikuti responden yang menghisap $>14$ batang rokok/ hari dan termasuk dalam kebiasaan merokok berat (28,3\%) (Tabel 3). Hal ini dapat disebabkan oleh kandungan nikotin dalam rokok yang membuat seseorang ketagihan sehingga ada keinginan untuk menambah jumlah batang rokok yang dihisap setiap hari. ${ }^{10}$

Data distribusi kebiasaan merokok berdasarkan lama merokok menunjukkan bahwa responden terbanyak yaitu yang menghisap rokok selama $>2$ tahun dan termasuk dalam kebiasaan merokok berat (39,4\%), diikuti responden yang menghisap rokok selama $<1$ tahun dan termasuk dalam kebiasaan merokok ringan $(37,4 \%)$ (Tabel 4). Hal ini didukung oleh penelitian yang dilakukan Miranti ${ }^{11}$ yang menjelaskan bahwa umumnya responden mulai merokok pada usia muda sehingga mereka sulit untuk berhenti merokok dan zat nikotin dalam rokok dapat membuat seseorang ketagihan untuk merokok.

Data status gingiva berdasarkan indeks gingiva menunjukkan bahwa responden yang memiliki status gingiva ringan (70,7\%), status gingiva sedang (26,3\%) dan status gingiva sehat (3\%) serta tidak ada responden yang memiliki status gingiva berat (Tabel 5). Hal ini tidak berbeda jauh dengan penelitian yang dilakukan oleh Pauraite (2003) menyatakan bahwa 43,6\% memiliki gingiva sehat, $47,2 \%$ inflamasi gingiva ringan, 9,2 \% inflamasi gingiva sedang dan tidak ada yang mengalami inflamasi gingiva berat. ${ }^{12}$

Hasil penelitian menunjukkan bahwa responden yang termasuk dalam kebiasaan merokok ringan berdasarkan jumlah rokok memiliki status gingiva ringan $(71,4 \%)$, sedangkan responden yang termasuk dalam kebiasaan merokok berat berdasarkan jumlah rokok memiliki status gingiva ringan yaitu sebanyak (57,1\%) (Tabel 6). Hal ini dapat terjadi karena kandungan nikotin dalam rokok dapat menghambat aliran darah, termasuk pada gingiva yang dapat menurunkan tanda-tanda klinis inflamasi. ${ }^{13}$ Penelitian yang dilakukan oleh Jan Bergstrom dan Hans Preber menyatakan bahwa reaksi inflamasi gingiva pada perokok kurang menonjol dibandingkan dengan non-perokok. ${ }^{14}$

Hasil penelitian menunjukkan bahwa responden yang termasuk dalam kebiasaan merokok ringan berdasarkan lama merokok memiliki status gingiva ringan (73,0\%), sedangkan responden yang termasuk dalam kebiasaan merokok berat berdasarkan jumlah rokok memiliki status gingiva ringan yaitu sebesar (59,0\%). Selain itu, terjadi peningkatan pada responden yang termasuk dalam kebiasaan merokok ringan berdasarkan lama merokok memiliki status gingiva sedang yaitu sebesar 18,9\% meningkat menjadi sebesar $41,0 \%$ responden yang termasuk dalam kebiasaan merokok berat berdasarkan lama merokok memiliki status gingiva sedang (Tabel 7). Hal ini dapat disebabkan karena terpaparnya asap rokok pada mukosa mulut sehingga semakin lama seseorang merokok maka semakin besar pula kemungkinan terjadinya penyakit gingiva. Hal ini selaras dengan penelitian yang dilakukan oleh Romelah di Semarang (2008) yang menyatakan bahwa ada hubungan antara tingkat keparahan gingivitis dengan lama merokok. ${ }^{15}$

\section{SIMPULAN}

1. Terdapat $49,5 \%$ remaja usia $15-19$ tahun di kecamatan Tuminting memiliki kebiasaan merokok ringan berdasarkan jumlah rokok (1-4 batang rokok/hari).

2. Terdapat $39,4 \%$ remaja usia $15-19$ tahun di kecamatan Tuminting memiliki kebiasaan merokok beratberdasarkan lama merokok ( $>2$ tahun).

3. Sebesar 70,7\% remaja usia 15-19 tahun yang memiliki kebiasaan merokok di kecamatan Tuminting memiliki status gingiva ringan.

4. Tidak ada hubungan antara kebiasaan merokok berdasarkan jumlah rokok dengan status gingiva pada remaja usia 15-19 tahun yang memiliki kebiasaan merokok di kecamatan Tuminting. 
5. Ada hubungan antara kebiasaan merokok berdasarkan lama merokok dengan status gingiva pada remaja usia 15-19 tahun yang memiliki kebiasaan merokok di kecamatan Tuminting dengan nilai $p<0,05$.

\section{SARAN}

1. Bagi Dinas Kesehatan perlu adanya peningkatan upaya promosi kesehatan kepada masyarakat tentang efek negatif rokok bagi tubuh terutama pada remaja.

2. Bagi para orang tua dari remaja yang merokok diharapkan dapat menjadi contoh figur yang baik bagi anakanaknya serta semakin meningkatkan pengawasan kepada anak untuk pencegahan dini terhadap kebiasaan merokok.

3. Dapat dijadikan bahan acuan untuk penelitian lebih lanjut mengenai hubungan kebiasaan merokok dengan status gingiva pada remaja dengan faktor-faktor yang lebih bervariasi dan jumlah responden yang lebih banyak.

\section{DAFTAR PUSTAKA}

1. Santrock JW. Adolescence perkembangan remaja. $6^{\text {th }}$ ed. Jakarta: Erlangga; 2003. p. 25-7.

2. Benjamin RM. A report of the surgeon general:Preventing tobacco use among youth and young adults. Centers for Disease Control and Prevention (CDC); 2012. p. 2-4

3. Schmidt L. The path to tobacco addiction starts at very young ages. Campaigns for tobacco free kids; Wahington, 2015. p. $1-3$

4. Kusuma ARP. Pengaruh merokok terhadap kesehatan gigi dan rongga mulut. Semarang: Majalah Sultan Agung; 2011;XLIX. Available from: http://www.unissula.ac.id.

5. Putri MH, Herijulianti E, Nurjannah $\mathbf{N}$. Ilmu pencegahan penyakit jaringan keras dan jaringan pendukung gigi. Jakarta: EGC, 2010; p. 26-35, 196-9

6. Badan Penelitian dan Pengembangan Kesehatan Kementerian Kesehatan RI. Riset Kesehatan Dasar. [online]. 2013 [cited 2015 May 6]. Available from: http://litbang.depkes.go.id

7. Mukti AG. Upaya pengendalian tembakau di Indonesia. [online]. Available from: http://ictoh.tcsc-indonesia.org

8. Yoto H, Anindita PS, Mintjelungan C. Gambaran gingivitis pada ibu hamil di puskesmas Tuminting kecamatan Tuminting kota Manado. Jurnal eGIGI. [serial online]. 2013 [cited 2015 May 10]. Available from: http://ejournal. unsrat.ac.id

9. Komasari D, Helmi AF. Faktor-faktor penyebab perilaku merokok pada remaja. Jurnal Psikologi. 2000;1:3747.

10. Proverawati A, Rahmawati E. Perilaku hidup bersih \& sehat. Yogyakarta: Nuha Medika, 2012; p. 103-9.

11.Miranti N. Hubungan kebiasaan merokok dengan menyikat gigi dengan keradangan gingiva. [Skripsi]. Jakarta: Universitas Indonesia, 2007; p.28-29

12.Pauraite J, Milciuviene S, Sakalauskiene J. The prevalence of gingivitis among 4-16 years old school children in Kaunas. Stomatologija, Baltic Dental and Maxillofacial Journal 2003;5:97100.

13.Jaya M. Pembunuh berbahaya itu bernama rokok. Yogyakarta: Riz'ma, 2009; p. 14-8, 49-50.

14.Bergstorm J, Persson L, Preber $H$. Influence of cigarette smoking on vascular reaction during experimental gingivitis. European Journal of Oral Sciences. 1988;96:34-39.

15. Romelah S. Hubungan kebiasaan merokok dengan tingkat keparahan gingivitis (Studi kasus pada anggota TNI AD Batalyon Infanteri 400/ raider Semarang). [Skripsi]. Fakultas Kesehatan Masyarakat UNDIP; 2008. 